\title{
Pripovedna empatija ter Cankarjeva romana Hiša Marije Pomočnice in Križna gori
}

\author{
Alojzija Zupan Sosič
}

Filozofska fakulteta UL, Oddelek za slovenistiko, Aškerčeva 2, 1000 Ljubljana, Slovenija https://orcid.org/0000-0003-2259-5861

alojzija.zupan-sosic@guest.arnes.si

Romana Ivana Cankarja Hiša Marije Pomočnice in Križ na gori (oba 1904) sem raziskala z analizo pripovedne empatije, in sicer bralčeve in avtorjeve empatije, z novim pristopom k pripovednim besedilom v postklasični teoriji pripovedi. Zanimalo me je, zakaj je prvi roman ob svojem izidu presegel bralčev horizont pričakovanja in stem dosegel tudi manjšo pripovedno empatijo pri bralcih, drugi pa je izpolnil horizont pričakovanja in s tem tudi večjo stopnjo pripovedne empatije na ravni recepcije. Pri avtorjevi empatiji sem upoštevala vse tri poti, tj. avtobiografičnost, visoko stopnjo avtorjeve empatičnosti in estetiko produkcije, pri bralčevi empatiji dve možnosti - identifikacijo z likom in pripovedno situacijo -, medtem ko sem v analizi primerjala tehnike empatiziranja. Neskladje med bralčevo in avtorjevo empatijo je namreč pokazalo, da je roman Hiša Marije Pomočnice ob izidu doživel manj pripovedne empatije zaradi manjšs bralčeve empatije, ker slovenski bralci ob začetku 20. stoletja niso zmogli deliti čustev in perspektiv ob tem Cankarjevem inovativnem romanu, in so se od njega odvrnili. Tudi razlika med literarno in trivialno empatijo je dokazala, da je Križ na gori zaradi svoje tradicionalnosti in manjše literarne kvalitete bolj ustrezal povprečnemu bralcu, odprtemu za trivialno empatijo, Hiša Marije Pomočnice pa zahtevnejšemu (literarnemu) bralcu in njegovi usmerjenosti k literarni empatiji.

Ključne besede: slovenska književnost / slovenski roman / Cankar, Ivan / pripovedna tehnika / literarna recepcija / obzorje pričakovanja / empatija / identifikacija / avtobiografskost

Romana Hiša Marije Pomočnice in Križ na gori (oba 1904) Ivana Cankarja (1876-1918) sta bila v literarni vedi že predstavljena in analizirana. Čeprav sta oba povzročila v bralcih velik čustveni in intelektualni odziv, njuna pripovedna empatija še ni bila sistematično ${ }^{1}$ raziskana.

${ }^{1} \mathrm{~S}$ pripovedno empatijo v enem od obeh obravnavanih romanov (v Hiši Marije Pomočnice) sem se doslej ukvarjala le avtorica te študije v angleški razpravi »Narrative 
Raziskavo pripovedne empatije obeh romanov bom izpeljala tako, da bom najprej razložila pomen empatije $\mathrm{v}$ današnjem času, nato pa oba romana osvetlila skozi perspektivo pripovedne empatije, enega najnovejših pristopov $\mathrm{k}$ analizam besedil $\mathrm{v}$ postklasični teoriji pripovedi. $\mathrm{Ob}$ tej napovedi se zastavlja logično vprašanje: zakaj sploh preučevati empatijo v Cankarjevih romanih. Odgovorov na to vprašanje je več, naj na začetku omenim samo dva. Prvi je vsekakor nujnost sodobnega, celo najnovejšega pristopa za uveljavljena romana po več kot sto letih njunega izida, drugi pa je možnost ponovne presoje odzivnosti pri obeh romanih, prav tako pa tudi analize pripovednih tehnik, ki so vplivale na sprožanje empatije in ugoden ali neugoden sprejem pri bralcih. Tako bom torej bralsko-kritiško situacijo obeh romanov v smislu izpolnjevanja in preseganja bralnega horizonta ponovno premislila ob avtorjevi in bralčevi empatiji ter treh tehnikah empatiziranja. ${ }^{2}$ Pri avtorjevi empatiji bom upoštevala vse tri poti, tj. avtobiografičnost, visoko stopnjo avtorjeve empatičnosti in estetiko produkcije, pri bralčevi empatiji dve možnosti - identifikacijo z likom in pripovedno situacijo -, medtem ko bom strateško empatiziranje avtorja opazovala skozi tri načine, tj. omejeno, ambasadorsko in razširjajočo empatijo.

Strokovnjaki so šele v devetdesetih letih prejšnjega stoletja ugotovili, da sta razmišljanje in čutenje (thinking and feeling) v istem "paketu«, kar so poimenovali čustvena inteligenca, ${ }^{3}$ nekateri nevroznanstveniki pa so celo skovali nov termin, kogmocija (cogmotions - Keen, Empathy 27), da bi poudarili zlitje kognicije in emocije. Ni naključje, da se je najbolj

Empathy in Two Novels by Ivan Cankar«, ki jo navajam v razdelku Literatura. Obe moji razpravi o pripovedni empatiji sta nastali v sklopu raziskovalnega programa št. P6-0265, ki ga je sofinancirala Javna agencija za raziskovalno dejavnost Republike Slovenije iz državnega proračuna.

${ }^{2}$ Angleško besedo emphatizing prevajam kot empatiziranje, čeprav ta beseda $\mathrm{v}$ slovenščini še ni uveljavljena ( $v$ hrvaščini je npr. že običajna). Svoj predlog prevoda empatiziranje - opiram na uveljavljeni glagolnik simpatiziranje (izpeljan iz nedoločnika simpatizirati), saj predvidevam, da dvojnost simpatija-empatija potrebuje dvojnost tudi v glagolskem smislu, torej simpatiziranje-empatiziranje. Podobna situacija dvojnice - sympathizing-emphatizing - je v angleščini že dolgo uveljavljena.

${ }^{3}$ Čustvena inteligenca ali čustvena inteligentnost poudarja kognitivne komponente v smislu mentalnih sposobnosti ter skupek nekognitivnih sposobnosti in kompetenc. Meddisciplinarna povezovanja, ki povezujejo pripoved in čustva, potekajo med naslednjimi področji: estetika, nevrobiologija, literarna teorija, literarna zgodovina, literarna interpretacija, evolucijska psihologija, kognitivna znanost, študije spola, socialna in razvojna psihologija, stilistika itd. Od teh si npr. kognitivna znanost (Gerrig 35) prizadeva razumeti celotno področje človeške izkušnje. Da bi to dosegla, njeni raziskovalci delujejo na več področjih, z literarnovednimi strokovnjaki pa se povezujejo predvsem na področju razumevanja zgodbe (story comprehension). 
sistematično posvetila čustvom prav postklasična teorija pripovedi, saj je pripovedni obrat ${ }^{4}$ povezal zanimanje za pripovednost in zgodbenost tudi s čustvi. Pripovedni obrat pa ni povečal samo znanstvenega zanimanja za empatijo, pač pa se je povezal tudi z interpretativnim in etičnim 5 obratom - empatija navsezadnje ni povezana samo s čustvi, temveč tudi z etiko. Velik vpliv na filozofe in naratologe imajo v zadnjem času razprave Marthe Nussbaum; njena prepričanost v moč (literarne) empatije deluje v dokaj materialistično naravnanem svetu precej idealistično in je podaljšek tradicionalnega razumevanja književnosti, ki ga Krznaric (169) razlaga kot tristoletno razpravljanje o vplivu fikcije na našo empatijo in etiko, ki je doseglo vrhunec v viktorijanski dobi.

Da bi lažje razumeli, kako danes znanstvena naklonjenost empatiji niha od ekstatične apologije do skeptične relativizacije, navajam dve znani trditvi trenutno najbolj priznanih strokovnjakinj za (pripovedno) empatijo, Marthe Nussbaum in Suzanne Keen. Prva meni,

da nas naša emocionalna vpletenost v romane Henryja Jamesa ali Charlesa Dickensa zaplete $\mathrm{v}$ procese empatije in razmišljanja, kar nas naredi boljše državljane $\mathrm{v}$ resničnem svetu. Zanimanje za literarne like, njihove okoliščine in potrebe, prebudi $\mathrm{v}$ nas moralne in politične interese, kar nas bo vodilo do pravih odločitev v prid neznanih drugih. (Nussbaum, Cultivating 90)

Trditev Suzanne Keen ( $A$ theory 212) deluje na prvi pogled povsem nasprotno, ko ugotavlja: »Moja dela poskušajo pojasniti, zakaj je vez med pripovedno empatijo in altruizmom tako ohlapna." Od bralca romana, ki doživlja ali empatijo ali osebno stisko, se ne pričakuje, da se bo odzval z recipročnim estetskim odzivom. Navedena trditev Suzanne Keen ni popolnoma nasprotna trditvi Nussbaum, saj ne zanika povezave empatije in književnosti oziroma branja ter empatije na splošno le skeptična želi biti do določenih znanih ugotovitev, predvsem do tistih, ki jih ne moremo natančno dokazati.

${ }^{4}$ Pripovedni obrat se imenuje tudi razcvet naratologije (Zupan Sosič, Postklasična 495); tj. proces v drugi polovici 20. stoletja, v katerem je postala osrednja literarna zvrst pripoved, njene tehnike in oblike pa so se selile celo preko literarnovednih meja. O delitvi naratologije na klasično in postklasično prav zaradi razcveta teorije pripovedi je pri nas prva pisala Alenka Koron v svoji doktorski disertaciji (2009), ki jo je leta 2014 predelano in razširjeno objavila v knjižni obliki (Sodobne teorije pripovedi). Najbrž ni naključje, da se je pripovedni obrat pojavil ravno konec prejšnjega stoletja in se tako povezal še s čustvenim, kognitivnim, interpretativnim in etičnim obratom.

${ }^{5}$ Tomo Virk (158) meni, da izhaja etični obrat po večini iz del Emmanuela Levinasa, enega najvplivnejših mislecev drugosti, pa tudi razmerja med literaturo in etiko v Evropi po holokavstu. Nedvomno pa je na razmerje etika - filozofija - književnost v zadnjih desetletjih pomembno vplivala tudi Marta Nussbaum. 
Nussbaum pri poudarjanju etične vloge književnosti izpostavlja pomen literarne domišljije; zdi se ji (Keen, Introduction 19-24), da bomo z zmanjševanjem pomena literarne domišljije izgubili bistveno povezavo z družbeno pravičnostjo - če se bomo odvrnili od domišljije, se bomo odvrnili od samih sebe. Pomen literarne imaginacije dokazuje s subverzivnostjo književnosti, saj književnost s svojo strukturo in načinom izražanja daje občutek življenja, ki ni usklajen z videnjem sveta, utelešenega $v$ tekstih politične ekonomije. Keen je dosti bolj skeptična do pomena književnosti za razvoj empatije, kar sem že nakazala. Ker se je do zdaj prav ona največ ukvarjala s pripovedno empatijo, bom v nadaljevanju predstavila njene ugotovitve, izvirajoče iz splošnega dvoma $\mathrm{v}$ vizijo, da družbeno dobro izhaja iz empatičnega branja - empatična bralna izkušnja, ki potrjuje povezavo empatije in altruizma, je po njenem mnenju prej izjema kot pravilo (Keen, Empathy 65). Dvom v moč empatije pa se je oglašal že prej: Keen (56) navaja najbrž najbolj znan napad na empatijo kot vidik umetniške recepcije v modernem času, ki ga je izpeljal Bertolt Brecht ${ }^{6}$ s svojim t. i. potujitvenim učinkom. Ta je zavračal empatijo $v$ prid razumske distanciranosti, kar pa je popolnoma nasprotno stališčem o nujnosti raziskovanja pripovedne empatije v današnjem času, ki jih zagovarja Keen: zavzema se za preučevanje intelektualnih in čustvenih vplivov romanov v kontekstu pozitivnih, nevtralnih in negativnih učinkov. Da bi lažje razumeli njene predpostavke in sklepe, najprej navajam opredelitve empatije, nato pa še pripovedne empatije.

Čeprav je empatija podobna identifikaciji, se vendarle od nje razlikuje: je psihična spoznavna sposobnost, $s$ pomočjo katere se človek prestavi na mesto neke druge osebe, dogodka ali pripovedne prvine, da razume čustva in namere (Andrieu in Boëtsch 118-119), a ni nujno, da pri tem občuti simpatijo, privrženost ali usmiljenje. Kot sposobnost vživljanja $v$ književnost je povezana s projekcijo vtisa na občinstvo (Popović 2010: 182), zaradi česar je v teoriji književnosti vezana predvsem na vprašanje učinka in recepcije. $Z$ drugimi besedami je empatija mehanizem (Zupan Sosič, Teorija 323), ki vodi razumevanje doživetja druge osebe; racionalno in čustveno dogajanje, ki temelji na sposobnosti postavljanja v položaj drugega oziroma vživljanja v drugega ali videnja sveta skozi oči drugega ter razumevanje njegovega sveta na način njego-

${ }^{6}$ Brecht se je v zagovoru nearistotelovske tradicije oprl na ruski »izum« potujitvenega učinka, in mu dodal zanimanje za kitajsko dramo, zanikanje iluzije četrte stene in pravil igranja po Stanislavskem. S sprevračanjem konvencij na obeh področjih dramaturgije je Brecht poskušal preprečiti ali vsaj zavirati avtomatični transfer gledalčevih čustev, pojav, ki ga je grajal kot čustveno okužbo (Keen, Empathy 56-57). 
vega čustvovanja in razmišljanja. Na področju literarne vede je trenutno najbolj raziskana prav pripovedna empatija (narrative empathy). V knjigi Narrative Form (Pripovedna oblika) je S. Keen (155) zgoščeno povzela svojo že v prejšnjih delih uveljavljeno definicijo takole: "[P] ripovedna empatija je deljenje čustev in perspektiv, ki jih sproža branje, gledanje, poslušanje ali zamišljanje pripovedi o situaciji in pogojih drugega." $\mathrm{V}$ isti knjigi vpeljuje avtorica (155-159) dve vrsti empatije, bralčevo in avtorjevo. V nadaljevanju se bom oprla na njene razlage obeh vrst pripovedne empatije; pri bralčevi empatiji bom upoštevala dve možnosti, pri avtorjevi empatiji pa tri poti. Medtem ko se bralčeva empatija pojavi, ko bralci, poslušalci in gledalci "ujamejo « čustva v neki predstavitvi, sledi avtorjeva empatija empatiji kot čustveno-intelektualni dejavnosti v času pisanja določenega dela in njegovega ustvarjanja na splošno.

Prva, t. i. bralčeva empatija, obsega čustva in perspektive, ki se pri občinstvu vzpostavijo do določenega besedila. Ta se glede stopnje bralčeve empatije razlikujejo, čeprav na bralčevo empatijo in njegovo vrednotenje vplivata dve vrsti medsebojno povezanih čustev in perspektiv. Prvo čustvo bralčeve empatije se običajno sproži pri stiku z (bežno) izkušnjo, ki se lahko skozi pripoved ponavlja, in vključuje spoznanje, da se bralčevi telesni občutki, razpoloženje in motivacija ujemajo $\mathrm{z}$ likom - to je klasična oblika bralčeve empatije, ki se pojavlja pri doživljanju identifikacije z literarno osebo. Seveda pa bralčeva empatija ni omejena samo na to prvo čustvo, poimenovano bralčeva identifikacija, ampak je povezana tudi z drugim čustvom, ko bralec čuti empatijo skozi prostorsko orientacijo v predstavljeni pokrajini oziroma kar v zgodbenem svetu samem. To empatijo sproži t. i. pripovedna situacija. Keen torej predlaga dve potezi pripovedne fikcije, ki sta največkrat povezani z bralčevo empatijo: identifikacijo z likom in pripovedno situacijo. Prva, identifikacija z likom, se opira na posebne ravni karakterizacije: poimenovanje, opis, posredno implikacijo značilnosti, opiranje na tipe likov, razlikovanje med njihovo ploščatostjo in zaobljenostjo, opisana dejanja, vloge $\mathrm{v}$ zgodbi, govor in načine posredovanja zavesti in nezavednega. Povezava med bralčevo identifikacijo z likom in njegovo empatijo še ni natančno pojasnjena (Keen, $A$ Theory 216-221), prav tako ne delovanje druge poteze, $\mathrm{t} j$. pripovedne situacije, tesno povezane $s$ perspektivo in fokalizacijo, kar pomeni načine mediacije med avtorjem in bralcem.

$\mathrm{Za}$ bralčevo empatijo je poleg bralčeve identifikacije pomembna tudi druga poteza pripovedi, imenovana pripovedna situacija. Ta je kot zbiralnik različnih tehnik, načinov in modelov povezana $\mathrm{z}$ avtorjevo empatijo, predvsem $s$ tretjo potjo, ki sem jo poimenovala estetika produkcije. Pripovedna situacija je torej odvisna od poetike časa in pro- 
stora, v katerem je besedilo ustvarjeno; saj prav poetika določene dobe, skupine ali posameznika usmerja pripovedne prvine, ki ustvarijo pripovedno situacijo, sestavljeno pretežno iz pripovedovalca, fokalizacije in literarne osebe. Pripovedna situacija obsega namreč kot mediacija (Keen, $A$ Theory 219) osebo, ki pripoveduje, implicitno vključenost pripovedovalca, odnos pripovedovalca in literarnih oseb ter notranjo ali zunanjo perspektivo likov, vključujoč stil predstavitve likove zavesti in nezavednega. Seveda obstaja še veliko drugih elementov, ki vplivajo na bralčevo empatijo, na primer ponavljanje prvin v serijah, dolžina romana, žanrska pričakovanja, "živa postavitev« dogajališč, metanarativni komentarji ter vidiki pripovedi, ki upočasnjujejo bralni tempo (zaznamovan besedni red, poudarjanje). $V$ teoriji pripovedi je splošno znano, da notranja perspektiva, dosežena s prvoosebno samonaracijo ali personalno pripovedjo ( $\mathrm{v}$ kateri tretjeosebni pripovedovalec pripoveduje le iz centra, umeščenega $\mathrm{v}$ glavni lik), pa tudi z avktorialno (vsevedno) pripovedjo, ki se premika znotraj likove glave, najbolje promovira identifikacijo z likom in bralčevo empatijo.

Bralčeva empatija, osvetljena skozi perspektivo bralčeve identifikacije in pripovedne situacije, se razlikuje od druge vrste empatije, imenovane avtorjeva empatija. Ta ponuja možnosti za analizo po treh poteh, ki sem jih razvrstila takole: avtobiografičnost, visoka stopnja avtorjeve empatičnosti in estetika produkcije. ${ }^{7}$ Prva pot, raziskovanje empatije s pomočjo avtobiografičnosti (Keen jih poimenuje autobiographical representations, tj. avtobiografske predstavitve), je že ustaljena, saj avtorji v različnih obdobjih oblikujejo svoje like tudi na temelju lastnih doživetij. Ivan Cankar, pesnik, pisatelj, dramatik in esejist ter osrednje ime slovenske književnosti, je prav znan po tem, da je v pripoved vnašal veliko avtobiografičnosti, ki je ni skrival ali se je sramoval, kar je značilno tudi za analizirana romana Hiša Marije Pomočnice in Križ na gori. Prvi roman je povezan z resničnimi izkušnjami, ki jih je znatno več kot v drugem romanu: glavna literarna oseba, bolna Malči, je oblikovana po resnični osebi Amaliji, mlajši sestri Cankarjeve zaročenke Štefke Löffler na Dunaju, s katero se je zelo zbližal in jo je od vseh v družini največkrat obiskoval v bolnici za neozdravljivo bolne. $\mathrm{V}$ drugem romanu lahko avtobiografičnost navežemo na Cankarjevo

${ }^{7}$ S. Keen na več mestih izpostavlja avtobiografičnost in visoko stopnjo avtorjeve empatičnosti, zaradi česar sem razlago prve in druge poti naslonila na njene predloge (Keen, „Narrative« 156), medtem ko o empatizirajočih tehnikah razpravlja manj sistematično in bolj fragmentarno; ne združi jih pod krovno tretjo pot. Sama menim, da je tudi estetika produkcije del avtorjeve empatije, zato jo navajam kot tretjo pot za razvoj bralčeve empatije. 
subtilno poznavanje umetnikov in slovenske umetnosti (na Dunaju) ter navdušenost nad uspehom slovenskih impresionistov na Dunaju.

Avtobiografičnost, prva pot raziskovanja Cankarjeve empatije, je tesno povezana $\mathrm{z}$ drugo potjo, tj. visoko stopnjo empatičnosti avtorja. Če avtor izkusi močna doživetja, jih bo verjetno lažje prepričljivo prelil v pripoved, hkrati pa bo postal bolj empatičen do različnih pojavov okrog sebe in v besedilu, kar ga bo avtomatsko navezalo na drugo pot razkrivanja avtorjeve empatije, ki sem jo navedla kot visoko stopnjo ${ }^{8}$ avtorjeve empatije. Cankar je namreč odraščal v revnem delavskem okolju na Vrhniki, kjer je zgodaj spoznal krivice brezdušnega kapitalizma, ki jih je prav tako kritično analiziral v Ottakringu, delavskem predmestju Dunaja, kjer je živel. To, da sta v obeh romanih glavni literarni osebi ženski, spet kaže na povečano avtorjevo empatijo, v tem primeru do spola, ki na začetku 20. stoletja še ni imel svojih pravic in pogosto tudi v literarnih delih ni nastopal polnokrvno in enakovredno. Za Cankarjeva besedila je prav značilno, da se s posebno subtilnostjo in naklonjenostjo, ki ju takrat še niso imenovali empatija - sam jo je imenoval odkritosrčnost ${ }^{9}$-, posvečajo brezpravnim bitjem, npr. ženskam, otrokom, revežem, brezposelnim, brezdomcem in bolnikom ter živalim. Drugo možnost za raziskavo visoke stopnje avtorjeve empatije ponuja teza, da imajo avtorji večjo zmožnost empatije, Keen (Narrative 156) npr. trdi, da so uspešni ustvarjalci praviloma bolj empatični od običajnih ljudi, kar se preverja iz njihovih pisem, intervjujev in javnega delovanja. Pisma in pogovori z Ivanom Cankarjem dokazujejo, da je pisatelj izrazil zelo veliko empatije do "ponižanih in razžaljenih", hkrati pa jo je dokazoval tudi z javnim delovanjem. Čeprav je približno dvanajst let živel na Dunaju, je bil natančno obveščen o družbenih krivicah v Sloveniji, in ker je želel tudi javno delovati v prid nižjih slojev, je kandidiral na socialdemokratski listi za deželnega poslanca. Njegovi socialistični nazori so izhajali iz takratnih naprednih delavskih gibanj

\footnotetext{
${ }^{8}$ Seveda pa avtorjeva empatija ni odvisna samo od izkušenj in empatičnih dejavnosti v resničnem življenju, saj je lahko pisatelj dosti bolj empatičen v svojih romanih kot v lastnem življenju ali obratno.

${ }^{9}$ Izidor Cankar (Ivan VI) razlaga bratrančevo odkritosrčnost takole: » [B]il je nasprotnik teoretičnih razprav o umetnosti in je imel sila preprosto 'estetiko', katere poglavitno in edino načelo je bilo: umetniško delo je lepo, če je 'odkritosrčno'. In ker je živel v tej dobi z dvema dušama, ker jo je doživljal vso, kar je je bilo, in ker mu je bilo vse pisanje le iskrena izpoved, ni bilo drugače mogoče, kakor da je elementarna sila sodobne naturalistične miselnosti zdaj pa zdaj pretrgala ideološko doslednost njegovega dela ter se sredi med drugačnimi pesnikovimi smermi uveljavila po svoje.« Seveda pa ne smemo pozabiti, da tovrstna odkritosrčnost ni nastopala zgolj v izpovedni ali pričevanjski vlogi, saj je imela večkrat družbenokritično ali satirično ost.
} 
in želje pomagati ljudem, kar jasno izražajo tudi njegova literarna dela, npr. v Hiš Marije Pomočnice razkrinkavanje in odpravljanje družbenih in družinskih tabujev, medtem ko se v Križu na gori zavzema za pravico do boljšega življenja, pri kateri izpostavi umetnost.

Tretja pot pri raziskavi avtorjeve empatije, poleg avtobiografičnosti in visoke stopnje avtorjeve empatije, je estetika produkcije ali poetika, način, pri katerem se avtorji trudijo vključiti strategije pripovedne empatije v svoje besedilo tako, da bi dosegli različne ciljne skupine bralcev in z različnimi pripovednimi tehnikami in prijemi (tudi) vplivali na njihovo empatijo. Estetika produkcije vključuje tudi prizadevanje, ki ga Keen (Narrative 156) imenuje avtorjevo prizadevanje za uporabo strateške pripovedne empatije, in je pravzaprav člen avtorjeve empatije, ki je že neposredno povezan z bralčevo empatijo ter nanjo najbolj vpliva. V času, ko je Cankar napisal oba romana, Hiša Marije Pomočnice in Križ na gori, so evropsko književnost zaznamovali realizem in smeri nove romantike, zato avtorjeva poetika vključuje zmes različnih literarnih smeri, vrst in žanrov. V tem času je naš pisatelj že opustil dekadenco ${ }^{10}$ in v prid «razsvetljevanja « Slovencev na začetku uporabljal zmes realizma in naturalizma, ki jo je kasneje zamenjal simbolizem, oplemeniten z impresionistično tehniko. Vse tri smeri, realizem, simbolizem in impresionizem, že same po sebi odpirajo vrata pripovedni empatiji: realizem poskuša čim natančneje predstaviti resnične podobe družbe in njene napake, simbolizem se obrača proti simbolnemu, lahko mističnemu, metafizičnemu ali magičnemu doživljanju sveta in tako odpira bralčevo "notranjost «, impresionizem pa z vtisi zunanjega in notranjega sveta sugerira različna razpoloženja in čustvena stanja.

K estetiki produkcije lahko štejemo, poleg sinkretizma realizma, simbolizma in impresionizma, tudi izbiro žanra: roman Hiša Marije Pomočnice je družbenokritični in urbani roman, Križ na gori je zmes ljubezenskega in razvojnega romana. Estetika produkcije na začetku 20. stoletja je bila v Sloveniji nekoliko drugačna kot drugje v Evropi, in zato si je Cankar še toliko bolj prizadeval preseči tradicijo z novimi smermi, žanri in pripovednimi tehnikami; na področju pripovedništva so pri nas takrat prevladovali predvsem vaška povest, zgodovinski, pustolovski in meščanski ljubezenski roman. Preseči tradicijo je Cankarju pomenilo ne le prenoviti literarne vzorce in obrazce, ampak vplivati tudi na etični, tu lahko uporabim besedo empatični obraz slo-

${ }^{10}$ Ivan Cankar je v znanem pismu Zofki Kveder, pomembni slovenski pisateljici, leta 1900 razložil svojo odločitev za realizem. Ker je želel reformirati slovensko književnost, se mu je zazdela dekadenca za slovenske razmere neprimerna. 
venstva. Preprosto povedano se je Cankar trudil prebuditi slovensko in evropsko bralstvo, zato je uporabljal sodobne pripovedne prijeme, ki so kot estetika produkcije umeščeni $\mathrm{k}$ avtorjevi empatiji.

Pravkar predstavljena razlaga bralčeve in avtorjeve empatije bo v nadaljevanju pomagala razložiti, zakaj je roman Hiša Marije Pomočnice ob izidu sprožil in doživel manj pripovedne empatije, Križ na gori pa znatno več. Pri razlagi avtorjeve empatije se bom pri vrstah avtorjeve strateške empatije - omejena, ambasadorska in razširjajočo empatija oprla na dela S. Keen kot najbolj priznane raziskovalke pripovedne empatije, medtem ko bom neskladje med avtorjevo in bralčevo empatijo navezala na horizont pričakovanja, tj. termin recepcijske estetike, česar omenjena raziskovalka sicer ni naredila. Če to stanje izrazim $s$ termini recepcijske estetike: Križ na gori je izpolnil takratni horizont pričakovanja in s tem doživel več pripovedne empatije pri bralcih, medtem ko ga je roman Hiša Marije Pomočnice znatno presegel, a pri tem izzval pri njih manj empatije. Bralčev horizont pričakovanja, kot ga je utemeljil Jauss (Pezdirc Bartol 203-204), sooblikujejo predhodno razumevanje književnih zvrsti, oblik in tematike že znanih del ter nasprotja med praktičnim, vsakdanjim jezikom in poetičnim jezikom dela, kar bralca vnaprej usmerja pri sprejemanju.

Problem izpolnjevanja horizonta pričakovanja ali usklajevanja avtorjeve in bralčeve empatije je lažje razumljiv, če vemo, da se empatija pri različnih ciljnih skupinah bralcev razlikuje, saj se stika z identitetami na različne načine. Ali se odzivamo na avtorjevo empatično pobudo zato, ker spadamo v neko skupino, ali pa se lahko empatija prikliče ne glede na vse meje in razlike med nami? Odgovorov je več in S. Keen ( $A$ Theory 224) jih povzema s klasifikacijo t. i. strateškega empatiziranja, razdeljenega na tri vrste. Prvo imenuje omejena strateška empatija; pojavlja se znotraj neke skupine, ki izhaja iz izkušenj vzajemnosti in vodi $\mathrm{k} \mathrm{ob/}$ čutenju s podobnimi drugimi. Druga, ambasadorska (ambassadorial) strateška empatija, naslavlja le izbrance $\mathrm{z}$ namenom kultivirati njihovo empatijo znotraj neke skupine, običajno z nekim specifičnim namenom, npr. s pozivom k prepoznavnosti, pravičnosti, pomoči. Primer za to vrsto empatije je roman Untouchable (Nedotakljivi, 1935), ki ga je v angleščini in za bralce izven kastnega sistema napisal Mulk Raj Anand. Tretja, razširjajoča strateška empatija, je usmerjena proti vsem bralcem, da bi za/čutili »čustveno zlitje« s poudarjanjem naših skupnih izkušenj, čustev, ranljivosti in upov. Ta empatija vključuje "univerzalnost", da bi se dotaknila vsakega in vseh, hkrati pa si prizadeva preseči principe podobnosti oziroma zgolj okoliščine tukaj in zdaj. Kenijski pisatelj Ngũgĩ wa Thiong'o npr. jasno vpeljuje razširjajočo strateško empatijo v 
svoje romane, provokativno vključujoč univerzalnost, večkrat zanikano s sodobnimi zagovori razlike.

Čeprav je Ivan Cankar dobro poznal kritiško situacijo v takratni Sloveniji, ki je občutno vplivala tudi na splošno mnenje in empatijo bralcev, je kljub temu pred izidom Hiše Marije Pomočnice še verjel, da bo knjiga uspešno sprejeta, saj je v pismu Anici Lušin (Kos 297) pisal, da mora ta knjiga uspeti, »drugače bi se mi zdelo, da naši ljudje res niso za drugega nego za abecednike«. Kako si je prizadeval, da bo z romanom vendarle segel do bralcev, dokazuje dolgotrajni proces pisanja, saj je avtor dlje časa pregledoval nekatera poglavja in odstavke, jih spreminjal in oblikoval, kar je odkrito priznal tudi svojemu založniku Schwentnerju. Sam je v pismu založniku menil, da je to »moje najbolj dovršeno delo" (Kos 300). Cankar si je tudi zamislil vse podrobnosti glede tiskanja, npr. debelino papirja, velikost knjige, ovitek, likovno opremo (zanjo predlaga Jakopiča), oblikovanje poglavij in odsvetovanje okraskov. Ker je bila knjiga že pol leta pri založniku, a še vedno ni šla v tisk, ga je zaskrbelo, zakaj Schwentner odlaša; svojo tesnobo in skrb ter neučakanost glede nove knjige je izrazil v več pismih. Franu Zbašniku je na primer v pismu napovedal, kako bo v novi knjigi uveljavil svojo neodvisnost od bralskih pričakovanj in zahtev ter predvsem lastno umetniško inovativnost. Iz tega pisma razberemo, da si je želel čimprejšnjega izida knjige tudi zato, ker bi knjiga dokumentirala njegovo pisateljsko neodvisnost in poetološko suverenost:

Veseli me prav od srca, da sem v svoji novi knjigi, ki izide pri Schwentnerju, tako korenito podrl nade tisočim ljudem, ki mislijo, da se bom 'ponarodil'! Kdor ne vidi v mojih mislih, v mojem čustvovanju, v mojem slogu, da sem Slovenec ter išče slovenstva ne v notranjem dejanju in razpoloženju, temveč $v$ zunanjostih, tisti je tujec sam in naj mi ne očita tujinstva. (Kos 303)

Cankarjevi skeptični občutki so se potrdili: knjigo so pričakale same negativne kritike, samo ena (anonimna, podpisana s kraticama P. M.) je bila pozitivna, objavljena v reviji Naši zapiski. Za celotno serijo kritik je bila pomembna prva obsežna kritika, ki jo je v Slovenskem narodu podpisal Fran Kobal - zaradi njegovih nazadnjaških načel in neargumentiranih trditev so nekateri tovrstno kritiko tudi v prihodnosti označevali kar »kobalovska kritika». Pisec je romanu (in na nekaterih mestih zelo jasno tudi avtorju samemu) očital rafinirano in umetniško dovršeno pornografijo, gnusnost, bolnost, iztrošenost (vzorovano po francoski družbi in književnosti), razblinjenost in nezdravo mistiko. Tej uničujoči kritiki so se pridružile še ostale negativne: npr. Cvetko Golar v Slovanu, Ivan Merhar v Ljubljanskem zvonu. Če so liberalni kritiki 
nihali od primitivnih do dobronamernih odklonitev, je katoliška kritika pokazala svojo nepopustljivost že s tem, da je roman skoraj zamolčala. Čeprav je Cankar podobne odzive pričakoval, ga je Kobalova kritika ${ }^{11}$ kljub temu močno prizadela, zato je najprej še želel odgovoriti nanjo, k čemur ga je vzpodbujal tudi Govekar, nato pa je odgovor preložil na uvod k romanu Gospa Judit, v katerem je izrazil svoje pomisleke glede bralcev in njihovega horizonta pričakovanja, pa tudi svoje umetniške nazore. $\mathrm{H}$ kritiki romana se je vrnil tudi $\mathrm{v}$ pogovorih $\mathrm{z}$ bratrancem Izidorjem $^{12}$ (Cankar, Obiski 9-10), ko je razmišljal, da je bil ta roman napačno razumljen.

Neskladje med avtorjevo in bralčevo pripovedno empatijo je povsem enako razliki med izpolnitvijo in preseganjem bralnega horizonta v obeh romanih: s Hišo Marije Pomočnice je Cankar znatno presegel bralni horizont, zato se avtorjeva in bralna empatija nista uskladili, medtem ko se je ravno obratno zgodilo v Križu na gori, ko je izpolnjeni horizont pričakovanja uravnovesil avtorjevo in bralčevo pripovedno empatijo. $Z$ drugimi besedami to pomeni, da sta bili obe situaciji bralčeve empatije (identifikacija z likom in pripovedna situacija) uspešnejši v Križu na gori, prav tako so bile takratnemu bralstvu bližje vse tri vrste avtorjeve empatije (avtobiografičnost, visoka stopnja avtorjeve empatije in estetika produkcije). Iz kritiških odzivov je tudi jasno, da je slovenskemu bralstvu na začetku 20. stoletja bolj ustrezala t. i. omejena strateška empatija, ki se uveljavlja znotraj neke skupine in vodi k občutenju podobnosti med bralci. Zakaj se bralci v romanu Hiša Marije Pomocnnice niso mogli poistovetiti $\mathrm{z}$ bolnimi dekleti in prav tako ne sprejeti novih pripovednih prijemov, ki jih prinaša njihova pripovedna situacija? Kaj pa jim je bilo tako všeč v Križu na gori, da so o njem pisali same pozitivne kritike? Začnimo kar s prvo potezo bralčeve empatije, torej z identifikacijo z likom.

"Drama" bolnih deklet, ki čakajo v bolnici na smrt, je večplastno branje, ki zahteva občutljivega, potrpežljivega in izurjenega bralca. Ne samo da roman odstopa od uveljavljenih literarnih konvencij, ampak

${ }^{11} \mathrm{~V}$ pismu Anici Lušin (Kos 320) je pisal o neupravičenosti zgražanja ob tej knjigi: "Zgražali so se nad to čisto knjigo ljudje, ki so umazani na duši in telesu; jaz pa sem jim odgovoril, kakor je treba umazancem odgovoriti. [...] Naj bo že, kakor hoče: to je gotovo, da ves slovenski filisterium mojega mezinca ni vreden!«

${ }^{12} \mathrm{~V}$ pogovoru z bratrancem Izidorjem Cankarjem (Kos 321) je pisatelj povedal: »Eno knjigo so mi popolnoma narobe, napak in hudobno razumeli. To je bila Hiša Marije Pomočnice. Pri njej sem imel kot studenec čisto misel. Ravno zato me je tista kritika ujezila, dasi je treba sicer velikih literarnih skandalov, preden pridem v jezo. Ideja hiše ni svinjarska, ampak tragična: štirinajst bolnih deklet, ki čakajo v smrti življenja in zdravja." 
se na vseh nivojih upira (meščanski) morali in poetiki, hkrati pa je tako večplasten, da ga $\mathrm{v}$ analizi ne moremo zaobseči samo z enovrstno razlago, npr. z analizo patoloških ljubezni in družbenega stanja, kar so največkrat počele kritike. Roman ni samo prefinjena klofuta egocentričnemu kapitalizmu, ampak tudi podoba patološkega stanja kot nove oblike lepote in hrepenenja k spiritualnosti ter čistosti kot nasprotju splošnega razkroja, kar je nedvomno še dediščina dekadence - prav prenikanje etike skozi estetiko pa je tista lastnost, ki je evropski fin de siècle skorajda ne pozna. Kaj je mislila kritika z oznakami nenaravnost, opolzkost, moralna oporečnost? Najlažje te oznake dešifriramo, če analiziramo različne ljubezni v romanu, ki so bile tudi kamen spotike večine odzivov, čeprav jih ti niso naravnost poimenovali ali jasno kritizirali. Čista otroška in svetniška materinska ljubezen v romanu $\mathrm{Na}$ klancu (1902), ki sta navdušili slovenske bralce, pojavita pa se spet v Križu na gori, nista vzbujali nobenih pomislekov, saj sta očitno aseksualni: v krajšem romanu Hiša Marije Pomočnice pa obe prevzameta spolne konotacije, saj matere ne opravljajo več zgolj altruistične materinske vloge, ampak so tudi strastne ljubice ter hladne in preračunljive žene, bolna dekleta pa niso več samo ubogljivi otroci, ampak tudi s spolnostjo zaznamovana bitja.

Osnovni problem recepcije in $s$ tem tudi bralčeve empatije je bil torej tradicionalne narave, saj so bralci pričakovali podobno podobo materinske in otroške ljubezni kot $\mathrm{v}$ prejšnjih romanih Tujci in $\mathrm{Na}$ klancu, a je niso dobili. Temu sta se pridružili še takratni nepoučenost in splošna zavrtost večinskega bralstva, saj so jih motili celo prikazi zunajzakonske, avtoerotične in lezbične ljubezni, zasidrane v književnosti že od realizma in naturalizma dalje; platonsko in spiritualno ljubezen, osrednji znanilki fin de siècla, pa so celo razglasili za neslovensko oziroma nepotrebno in iztrošeno dekadenčno spremljevalko. Da ne omenjam patoloških ljubezni v obliki različnih spolnih zlorab, ki so jih moralizatorski kritiki obsodili kot mesta naslajanja oziroma pornografije, saj v njih niso znali razbrati subverzivnega potenciala družbene kritike $v$ funkciji razkrivanja algolagnije kapitalizma ali preprosteje: sredstva odkrivanja in odpravljanja tabujev. Za meščanski svet $\mathrm{v}$ času izida romana sta bila seksualizacija otroštva in materinstva ter njuna demitizacija zelo inovativna (seveda nezaželena) pristopa, ki sta rahljala in celo rušila meščansko etiko. Nadzor človekove spolnosti je imel takrat posebno mesto $\mathrm{v}$ moralnih prizadevanjih in ga je bilo $\mathrm{v}$ meščanskem oziru mogoče vzpostaviti le v družini. Problema pri bralcih ni predstavljal samo eros, pač pa tudi tanatos oziroma večplastnost smrti, kar Kermauner (103) označuje kot optimizem smrti (optimistični mortualizem), izpeljan na povsem inovativen način. 
Križ na gori je v nasprotju z romanom Hiša Marije Pomočnice zanemaril provokativnost erotike in Cankarjevo osnovno vodilo poetike od pesniške zbirke Erotika (1899) dalje - seksualnost je prostor subverzije; ta je v romanu Hiša Marije Pomočnice šokirala tudi zaradi prostodušnosti, iskrenosti in odkritosrčnosti otroške perspektive. Poleg angelske in s tem neprovokativne podobe glavne literarne osebe Hance (imenovane kar angel varuh), ki je požrtvovalna, zvesta in vdana, je $\mathrm{k}$ pohvali romana Križ na gori in s tem tudi večji pripovedni empatiji nedvomno prispevala še optimistična perspektiva. Če je Cankar v povesti Sreča še izražal dvom o razstavi slovenskih impresionistov na Dunaju in celotnem položaju slovenske umetnosti, ga je nepričakovan uspeh slovenskih umetnikov tako navdušil, da se je njegovo optimistično razpoloženje naselilo tudi v Križ na gori. Prav pesimizem pa je očitek, ki so ga Cankarju večkrat zapisali že v kritikah prejšnjih del, v katerih so mu predlagali optimistično držo. Hkrati si je slovenska javnost oddahnila, ko je Cankar napisal ljubezensko zgodbo, kar je označil že v podnaslovu, saj se je z žanrsko izbiro ljubezenskega romana vsaj delno odrekel svoji klasični kritičnosti, satiričnosti in jedkosti in s tem drezanju $\mathrm{v}$ boleče rane slovenske umetnosti in politike.

Tudi druga vrsta bralčeve empatije, ki izhaja iz pripovedne situacije, prav tako dokazuje preseganje horizonta pričakovanja $\mathrm{v}$ romanu Hiša Marije Pomočnice ter izpolnitev tega horizonta v Križu na gori. Pripovedna situacija namreč kot mediacija obsega (Keen, $A$ Theory 219) osebo, ki pripoveduje, implicitno vključenost pripovedovalca, odnos pripovedovalca in literarnih oseb ter notranjo ali zunanjo perspektivo likov, vključujoč stil predstavitve likove zavesti in nezavednega. Čeprav je Cankar v obeh romanih uporabil tretjeosebnega in personalnega pripovedovalca, se med seboj razlikujeta. $\mathrm{V}$ prvem romanu ta sistematično preplete zavedne situacije z nezavednimi, saj večpomenskost $H i{ }^{2} e$ Marije Pomočnice temelji na poetiki simbolov, torej vizij, sugestij in aluzij. Prav tako je v tem romanu moderno (tudi modernistično, saj lahko Cankarja razlagamo celo kot predhodnika slovenskega modernizma) premikanje perspektive od ene deklice $\mathrm{k}$ drugi, ko spoznamo kar štirinajst različnih zgodb vseh bolnic, in čeprav je Malči osrednja literarna oseba, ne deluje kot klasična povezovalka kompozicije. Poleg otroške perspektive, ki je bila s svojo odkritosrčnostjo in nefiltriranostjo povsem nov element pripovedne situacije, je Cankar šokiral tudi $s$ posebnim vojerizmom, ki ga Kermauner (105) imenuje dvojni odnos do gledanega. Po njegovem so dekleta, ki morajo gledati spolne zablode, do gledanega v dvojnem odnosu: na eni strani jih gledano odbija, se jim gnusi, jih poškoduje, na drugi pa jih privlači, ne morejo odtegniti 
pogleda, $v$ gledanem celo uživajo, še huje, uživajo celo v lastni nemoči bega, v lastnem gnusu.

Če položaj romanov Hiša Marije Pomočnice in Križ na gori premislimo še skozi perspektivo treh vrst empatiziranja, ugotovimo, da prvega praviloma označuje razširjajoča strateška empatija, drugega pa omejena strateška empatija. Pri pisanju drugega romana je Cankar pretežno nagovarjal povprečnega slovenskega bralca, vzgojenega $\mathrm{v}$ patriarhalnem in katoliškem duhu, za katerega literarna zgodovina beleži tradicionalnost kot zožano perspektivo in manjšo strpnost do drugačnosti. Cankar je namreč povprečnega slovenskega bralca zelo dobro poznal in mu $s$ svojimi romani želel predrugačiti horizont pričakovanja, $s$ tem pa tudi stopnjo pripovedne empatije; najbolj očitno ga nagovarja v prvem delu romana Gospa Judit, ki je pravzaprav odziv na negativne kritike Hiše Marije Pomočnice, kjer mu očita ozkosrčnost, moraliziranje in napačno kritičnost. Mogoče je Cankar tudi zaradi neuspele empatije Hiše Marije Pomočnice v tako kratkem času napisal roman Križ na gori in že med pisanjem na več mestih izrazil svoj optimizem glede sprejema - v pismu uredniku Levcu napoveduje svoj roman za Slovensko matico kot povest za večji krog bralcev: »Ustregel sem Vam, upam, to pot tudi v tem oziru, da Vam pošiljam tako povest, ki bo tudi za širše občinstvo (Bernik 424).

Primerjava obeh vrst empatiziranja pokaže, da je znatno težje izpeljati tretjo vrsto empatije, t. i. razširjajočo strateško empatijo, saj jo je treba usmeriti preko ustaljenih norm in izven skupine isto mislečih in čutečih bralcev. Prav zato se je Cankar na pisanje romana Hiša Marije Pomočnice dlje časa pripravljal, ga neverjetno dolgo pilil (cel proces je trajal štiri leta, medtem ko je Križ na gori napisal v enem mesecu), v času pisanja je preverjal svoje postopke $\mathrm{v}$ pogovorih $s$ prijatelji, bil je stalni obiskovalec bolnice, v kateri je bivala Štefkina sestra Malči. Kot sem že prej omenila, je Cankar večkrat očitno pokazal svojo empatijo, predvsem jo je izražal do bolne Malči, ${ }^{13}$ ki so jo poslali v bolnišnico Das Haus der Barmherzigket (odkar so to bolnišnico porušili, "živi« samo še v tem romanu), kjer jo je od vseh članov družine Löffler največkrat obiskal prav Cankar, ki se je dobro razumel tudi z drugimi bolnicami. Ker se je zavedal, da piše poseben roman, je želel vse prizore dobro premisliti in si jih natančno predstavljati, zato jih je risal, prav tako si je začrtal zapleteno kompozicijo. Da si bralci niso želeli razširjajoče strateške empatije, pač pa omejeno empatijo, dokazujejo že prejšnje kritike,

${ }^{13}$ Štefka Löffler je poročala, da se je Cankarju na obrazu videlo, kako mu je bilo hudo ob odhodu Malči v bolnico, še bolj ga je bolelo, da je neozdravljivo bolna. V bolnici jo je večkrat obiskoval in govoril o njej, kako potrpežljivo prenaša svojo usodo (Kos 294). 
ki so Cankarju poleg ostalih pomanjkljivosti očitale tudi neslovenskost. V romanu Hiša Marije Pomočnice so tovrstne kritike našle potrditev že v sami izbiri dogajalnega prostora: roman se namreč dogaja v Avstriji, v dunajski (ne pa slovenski!) bolnici, prav tako so romanu očitale še tuje (francosko) razpoloženje in vnos "neslovenskih" literarnih praks.

Pridružujem se mnenju Keen (Empathy 69), da tudi slabo napisane knjige ali stereotipni liki na splošno lahko izzovejo empatijo, kar večkrat moti izurjene oziroma zahtevnejše bralce, ki menijo, da to ni prava empatija. Tudi sama menim, da vendarle gre za empatijo in naj se tudi tovrstna empatija preučuje; ker pa se mi ne zdi povsem enaka empatiji izkušenega ${ }^{14}$ bralca $v$ stiku s kvalitetno knjigo, ločujem med trivialno in literarno empatijo. Čeprav za roman Križ na gori ne bi mogla trditi, da je trivialen, je pa od vseh Cankarjevih romanov najmanj kvaliteten in prav zato predvideva drugačno pripovedno empatijo, poleg literarne tudi trivialno empatijo. Medtem ko literarna empatija omogoča razumevanje tuje izkušnje ter možnost razpiranja drugačnosti in odprtosti do drugega, trivialna empatija kot del zunajbesedilne trivialnosti zavrača izkušnjo drug/ačn/osti, saj trivialni bralec uživa le ob znanem, npr. ob uveljavljenih vzorcih, obrazcih, postopkih in temah. Običajno je trivialna empatija značilna za neliterarnega oziroma trivialnega bralca, ki se zaradi primanjkljaja $\mathrm{v}$ bralni kompetenci omeji le na poistovetenje (Zupan Sosič, Teorija 377) z likom ali dogajanjem (a tudi lik in dogajanje morata biti prilagojena njegovi zožani kompetenci), povabila $\mathrm{k}$ drugosti pa ne sprejme. $\mathrm{V}$ zvezi s sprejemanjem neznanega/ drugega/drugačnega naj ponovim Adornovo (69-100) misel, kako trivialna literatura samo izpolnjuje horizont pričakovanja in $s$ tem ponuja (potrošniškemu) bralcu možnost ostati takšen, kakršen je, medtem ko umetniška literatura zahteva od bralca muko pozabe in znajdenja v drugosti literarnega sveta.

Kljub nekaterim kvalitetnim lastnostim v romanu (osrednjost ženske literarne osebe in možnost za njeno boljše življenje, perspektive drugačnega življenja) ima roman nekaj pomanjkljivosti oziroma nedodelanosti na zgodbeni in pripovedni ravni v smislu trivializacije, ${ }^{15}$ kar odpira več

${ }^{14}$ Izkušenega bralca nekateri imenujejo tudi strokovni bralec, sama pa sem ga glede na ločevanje branja na literarno in neliterarno branje imenovala literarni bralec. Ta bere predano, poznavalsko, poglobljeno, ustvarjalno, interpretativno-analitično, intenzivno in upošteva dvostopenjsko branje ter se k nekaterim knjigam vedno znova vrača. Njegovo nasprotje je neliterarni (tudi trivialni) bralec, ki bere naivno, površno, zgolj intuitivno in predvsem prvostopenjsko (Zupan Sosič, Teorija 253-296).

${ }^{15}$ Trivializacija je postopek vnašanja trivialnih značilnosti v netrivialno besedilo ali preigravanje z njenimi značilnostim (Zupan Sosič, Teorija 376). Rezultat nedosledno 
poti trivialni empatiji. Na zgodbeni ravni je to klasična prostorska dvojnost: Globel je prostor zaostalosti, ozkosrčnosti, temačnosti, oddaljeno (neimenovano) mesto pa možnost osebne rasti. Prostorska dvojnost je tudi opisana stereotipno, saj je Globel temna, utesnjena in mrzla, primerja se celo z rakvijo, grobom in pokopališčem, mesto pa je praviloma svetlo, široko in veselo. V Globel namreč nikoli ne posije sonce in samo če literarna oseba stopi na bližnji hrib, jo lahko obsije sončni žarek. Prav tako kot se ponavljata barvna in razpoloženjska simbolika v smislu temna Globel - sončno mesto, se ponavljajo tudi razpoloženjski vtisi, ki jih dokaj shematično označi tradicionalna simbolika: križ je simbol trpljenja, na koncu tudi rešitve, zvon notranjega razpoloženja, medtem ko senca simbolizira slutnjo ter sončni žarek veselje in toplino. Na pripovedni ravni je simplifikacija največji kazalnik prilagajanja bralnemu horizontu in s tem tudi trivialni empatiji. Ne samo karakterizacija, poenostavljeni so tudi dialogi, zgradba oziroma kompozicija romana ter začetek in konec romana.

Karakterizacija Hance, petnajstletne mežnarjeve hčerke, zaljubljene v slikarja Mateta, je namreč znatno manj inovativna kot upodobitev glavnih likov v Hiši Marije Pomočnice. Kot tip vdane, požrtvovalne in zaščitniške ženske je Hanca ustrezala stereotipnim pričakovanjem slovenskega bralstva. Hanca potrpežljivo čaka na Mateta, ki je v tujini uspel in pozabil nanjo. Njegovo odtujenost in številne ljubice poskuša vitalistično opravičiti z upanjem, da se bo spet spomnil nanjo in spoznal vrednost njene žrtvujoče se ljubezni, kar močno spominja na Bertine upe v prvem Cankarjevem romanu Tujci in Franckine želje v drugem romanu $\mathrm{Na}$ klancu. Tip trpljenjske, žrtvujoče se in odpuščajoče ženske je bil slovenskemu bralstvu že znan iz slovenske klasike ter prejšnjih Cankarjevih romanov in pripovedi, zato so ga zdaj sprejeli z odprtimi rokami, hkrati pa je to tip ženske, ki je ustrezal patriarhalni in katoliški miselnosti tistega časa. Kar je novo v njeni karakterizaciji in presega zgolj model tradicionalne ženske, je prav moč upreti se vaški skupnosti in jo zapustiti - ta lastnost je tudi edina, ki poskuša lik iztrgati iz črno-bele karakterizacije. Čeprav je Hanca Matetovo dekle, so izpostavljene samo njene skrbniške lastnosti, ki so ji družbeno pripisane kot edine možne plasti identifikacije. Tudi poimenovana je angel varuh, zato nima nobenih telesnih, kaj šele spolnih konotacij; ovija jo svetniški sij stereotipa hišni angel. ${ }^{16}$ Zoženje Hance na zgolj abstraktno duhovno

izpeljane trivializacije je trivializirano besedilo, kar je tudi roman Križ na gori; vendar pa ta roman ni trivialno besedilo, saj v njem trivialnost ni vrhovno načelo.

${ }^{16}$ Hišni angel je izraz, ki ga je »izumila» Virginia Woolf, da bi z njim razkrinkala orokavičeno sakralizacijo ženske. Ženski se namreč prisodi angelske atribute zgolj zato, 
(celo materinsko) počelo je toliko bolj očitno v primerjavi z Matetovo ljubico, lepo učiteljico, ${ }^{17} \mathrm{ki}$ pa je poosebitev telesnosti - karakterna delitev ženskih likov na dvojnice, tj. duhovne in telesne ženske se že približuje črno-beli karakterizaciji.

Podobna poenostavitev je vidna tudi na kompozicijski ravni, ko se dogodki napovedujejo predvidljivo, opisi posameznih razpoloženj se ponavljajo, simbolika je v dogajanje vpeta dokaj pragmatično in zato premalo sugestivno. Roman se začne z zvonjenjem in s čudežem. Hanca se namreč po tolažbo zateče v cerkev, kjer se Mati božja ozre nanjo, kar seveda pomeni, da jo bo - kljub njenemu križevemu potu - spremljala sreča, ki se potrdi s srečnim koncem oziroma skupnim odhodom iz Globeli. Pomenljiv je tudi prvi dogodek: Hanca sreča Mateta, ki nese župniku prodat svojo sliko. Vzame mu velik zavoj, prevelik za njeno drobno otroško-žensko telo, in si ga naloži na hrbet, kar jo popolnoma sključi. To veliko breme je seveda ne moti, saj to dejanje pomeni, da je vzela križ na svoje rame in bo zdaj ona tista, ki bo trpela za oba, zase in Mateta. Tudi konec romana deluje predvidljivo, hitra spreobrnitev Mateta iz neodgovornega ženskarja in veseljaškega skeptika v zvestega bodočega ženina pa manj motivirano. Hanca na koncu romana spet zvoni, in ker zapušča Globel, je v zvoku velikega zvona »nekaj slovesnega in veselega, kakor da bi zvonila k prazniku“ (Cankar, Križ 233). Ko se pojavi Mate, se kakor nebeška glorija sveti za njim večerna zarja, in ko se objameta, zagleda učitelj na hribu podobo velikega križa. Ta je bil na začetku romana in tudi v nadaljevanju simbol trpljenja, tu pa izkoristi še svoj drugi pomenski naboj: za objeta zaljubljenca nedvomno pomeni rešitev. Zaradi vseh naštetih razlik mi na koncu razprave ne bo težko odgovoriti na vprašanje, ki ga je $\mathrm{v}$ več različicah različnim skupinam bralcev v svojih (empiričnih) raziskavah zastavila S. Keen

da se ji skrči življenjski prostor na hišo oziroma njene skrbniške naloge v smislu, naj svoje gospodinjske zadolžitve opravlja vdano, potrpežljivo in tiho, tako kot angel, in se pri tem ne pritožuje niti ne moti ostalih s svojim gospodinjskim delom. Woolf je $s$ paradoksalnostjo besedne zveze problematizirala prisilno domestifikacijo ženske, s tem pa tudi njeno drugorazrednost, ki je najbolj prefinjeno prikrita prav s podoba angela. Povezava angela in hiše namreč pervertira žensko »naravno« držo in jo izmika »učlovečenju« oziroma enakopravnosti z moškim spolom.

${ }^{17}$ Lepa učiteljica je kot ljubica opisana zgolj s telesnimi atributi in tako zreducirana le na telo: je bujno razvita, oblečena v kratko in živo pisano krilo, izza rdečega modrca se svetijo čipkasti rokavi, ki razkrivajo gole gosposke roke, na belem drobnem obrazu rdijo polne ustnice, glas je globok, moški in dišeč po cigaretnem dimu ... Je sicer dobra igralka, a ravno ta lastnost je za ljudsko mnenje diskriminatorna: kot igralka se ne zdi iskrena v življenju, hkrati pa ji že sam poklic, v našem primeru amaterska dejavnost, prilepi oznako lahkoživke. 
(Empathy 66): kateri roman je na vas vplival tako, da ste naredili ali mislili kaj specifičnega. Ker je moj odgovor Hiša Marije Pomočnice, ta odločitev tudi pomeni, da je prav ta roman v meni sprožil več pripovedne empatije.

\section{LITERATURA}

Adorno, W. Theodor. Beležke o literaturi. Prev. M. Savski idr. Ljubljana: Cankarjeva založba, 1999.

Andrieu, Bernard, in Gilles Boëtsch, ur. Rečnik tela. Prev. Olgica Stefanović. Beograd: Službeni glasnik, 2010.

Bernik, France. Opombe. Ivan Cankar. Zbrano delo. 12 (Gospa Judit, Križ na gori, Novele in crtice 1903-1904). Ljubljana: DZS, 1970.

Cankar, Ivan. Zbrano delo. 12 (Gospa Judit, Križ na gori, Novele in črtice 1903-1904). Ur. France Bernik. Ljubljana: DZS, 1970.

Cankar, Ivan. Zbrano delo. 11 (Hiša Marije Pomočnice, Mimo življenja). Ur. Janko Kos. Ljubljana: DZS, 1972.

Cankar, Ivan. Zbrano delo. 22 (Moje življenje, Grešnik Lenart). Ur. Janko Kos. Ljubljana: DZS, 1975.

Cankar, Izidor. Opombe. Ivan Cankar. Izbrani spisi. Ur. Izidor Cankar. 6. Ljubljana: Nova založba, 1927.

Cankar, Izidor. Obiski. Ljubljana: Nova založba. 1920.

Gerrig, J. Richard. "Why Literature is Necessary, and not Just Nice». Cognitive Literary Studies: Current Themes and New Directions. Ur. Isabel Jaén in Julien Jacques Simon. Austin: UP Texas Press, 2012.35-53.

Hoffman, Martin L. "Empathy and Prosocial Behavior«. Handbook of Emotions. Ur. Michael Lewis, Jeannette M. Haviland-Jones in Lisa Feldman Barrett. New York in London: The Guilford Press, 2008. 440-456.

Jauss, Hans Robert. Estetsko izkustvo in literarna hermenevtika. Prev. Tomo Virk. Ljubljana: Literarno-umetniško društvo Literatura, 1998.

Keen, Suzanne. »A Theory of Narrative Empathy«. Narrative 14/3 (2006): 207-236. Tudi na spletu.

Keen, Suzanne. Empathy and the Novel. Oxford; New York: Oxford UP, 2007.

Keen, Suzanne. "Introduction: Narrative and the Emotions«. Poetics Today 32/1 (2011): 1-53. Tudi na spletu.

Keen, Suzanne. "Narrative Empathy (Definition and Explication)«. The Living Handbook of Narratology. Ur. Peter Hühn. Hamburg: University of Hamburg, 2013. Tudi na spletu.

Keen, Suzanne. Narrative Form. New York, London: Palgrave Macmillan; St. Martin Press, 2015.

Kermauner, Taras. Spremna beseda in opombe. Ivan Cankar. Hiša Marije Pomočnice. Ljubljana: Mladinska knjiga, 1974. 99-113.

Koron, Alenka. Sodobne teorije pripovedi. Ljubljana: Založba ZRC, ZRC SAZU, 2014.

Kos, Janko. Opombe. Ivan Cankar. Zbrano delo. 11 (Hiša Marije Pomočnice, Mimo življenja). Ljubljana: DZS, 1972. 285-340.

Krznaric, Roman. Empatija: temeljna kvaliteta za ostvarivanje revolucionarnih promjena u 21. stoljeću. Prev. Aleksandra Barlović. Zagreb: Planetopija, 2014.

Nussbaum, Martha. Cultivating Humanity. Cambridge: Harvard UP, 1997. 
Nussbaum, Martha C. Pjesnička pravda. Književna imaginacija i javni život. Prev. Marina Miladinov. Zagreb: Naklada Deltakont, 2005.

Pezdirc Bartol, Mateja. „Vloga bralca v poglavitnih literarnoteoretičnih smereh 20. stoletja: I. del«. Jezik in slovstvo 45/5 (1999/2000): 195-205.

Popović, Tanja. Rečnik književnih termina. Beograd: Logos Art, 2010.

Reissland, Nadja. The Development of Emotional Intelligence. New York: Routledge, 2012.

Schneider, Ralf. Emotion and Narrative. Routledge Encyclopedia of Narrative Theory. Ur. David Herman, Manfred Jahn, Marie-Laure Ryan. London, New York: Routledge, 2008. 136-137.

Virk, Tomo. Etični obrat v literarni vedi. Ljubljana: Literarno-umetniško društvo Literatura, 2018.

Zupan Sosič, Alojzija. "Narrative Empathy in Two Novels by Ivan Cankar«. Problemi slovjanoznanstva (Problems od slavonic studies) 66. Lviv: Ivan Franko National University, 2017. 102-112.

Zupan Sosič, Alojzija. »Postklasična teorija pripovedi.« Slavistična revija 61/3 (2013): 495-507.

Zupan Sosič, Alojzija. Romani. Ivan Cankar: literarni revolucionar. Ur. Aljoša Harlamov. Ljubljana: Cankarjeva založba, 2018. 201-235.

Zupan Sosič, Alojzija. Teorija pripovedi. Maribor: Litera, 2017.

\section{Narrative Empathy and Ivan Cankar's Novels The Ward of Mary Help of Christians and The Cross on the Mountain}

Keywords: Slovenian literature / Slovenian novel / Cankar, Ivan / narrative technique / literary reception / horizon of expectation / empathy / identification / autobiographical representation

This article explores narrative empathy associated with the novels The Ward of Mary Help of Christians and The Cross on the Mountain (both from 1904) by Ivan Cankar (1876-1918) in order to find out why the former, upon its publication, exceeded the readers' horizon of expectation, thereby achieving less narrative empathy in readers, while the latter met their expectations to a greater degree at the receptive level, thus evoking more narrative empathy. I consider three paths, i.e. autobiographical representation, a high level of author's empathy, aesthetics of production and the two possibilities for the readers to empathize - identification with the character and the narrative situation. The empathizing is also analyzed according to the three modes, so-called bounded, ambassadorial, and broadcast empathy. The disharmony 
between the empathy of the author and the reader shows that the novel The Ward of Mary Help of Christians received less empathy not because of the defectiveness of the empathy in the author but because of the defectiveness of the empathy in the readers of the novel. At the beginning of the twentieth century, Slovenian readers were unable to share the emotions and perspectives of this innovative novel, which is why they preferred the The Cross on the Mountain. To explain the disharmony between the empathy of the author and the reader, the distinction between literary and trivial empathy also had to be taken into account; this difference again proves that the novel The Cross on the Mountain was suitable for the average reader open to trivial empathy, while The Ward of Mary Help of Christians required more demanding literary readers and their orientation towards literary empathy.

1.01 Izvirni znanstveni članek / Original scientific article UDK 821.163.6.09-31Cankar I.

D0I: https://doi.org/10.3986/pkn.v43.i1.13 